\title{
MACC1 wt Allele
}

National Cancer Institute

\section{Source}

National Cancer Institute. MACC1 wt Allele. NCI Thesaurus. Code C106604.

Human MACC1 wild-type allele is located in the vicinity of 7p21.1 and is approximately 83 $\mathrm{kb}$ in length. This allele, which encodes metastasis-associated in colon cancer protein 1 , is involved in promoting both cell motility and cell proliferation. Expression of this gene in colon cancers is a prognostic indicator for metastasis formation. 